\title{
The application of ergative verbs to avoid accusations in the translation of Chinese editorials into English
}

\author{
Dahui Dong ${ }^{1} \&$ Mu-Li Yang ${ }^{2}$ \\ ${ }^{1}$ Department of Translation and Interpretation Studies, Chang Jung Christian University, Taiwan \\ ${ }^{2}$ Department of Mass Communication, Chang Jung Christian University, Taiwan \\ dongdahui@mail.cjcu.edu.tw,yml320@yahoo.com.tw
}

\begin{abstract}
Dahui Dong \& Mu-Li Yang. The application of ergative verbs to avoid accusations in the translation of Chinese editorials into English. The Poznan Society for the Advancement of Arts and Sciences, PL ISSN 0079-4740, pp. 17-32

The use of ergative verbs results in the agent being backgrounded in an English sentence, and it is often used in the media together with other means such as the use of intransitive verbs, passives, and nominalized nouns to achieve the pragmatic purpose of accusation avoidance. A great deal of research has been done on the role of ergative verbs in media discourse in English as well as the acquisition of ergative verbs by learners of English as a Foreign Language (EFL). However, it remains unclear how EFL Chinese learners of advanced levels of competence, such as postgraduates of translation majors and professional translators, use ergative verbs when translating newspaper editorials from Chinese into English. Nor is it clear whether learners have acquired the requisite knowledge of ergative verbs in order to use them effectively so as to avoid blaming the agent of an action or process in translation. This study recruited 30 native Chinese-speaking translators who fell into three categories: undergraduate translators, graduate translators, and professional translators. A small parallel translation corpus was built, which consisted of 150 English translations of 5 Chinese editorials produced by the translators. Accusation-avoidance expressions in the source text and their translations were then extracted and input into an SPSS spreadsheet. The results show that the use of ergative verbs in translations by undergraduate translators is significantly higher than in translations by graduate and professional translators in terms of quantity. The results of the study may be useful for translation teaching and learning.
\end{abstract}

Keywords: ergative verbs, accusation-avoidance, translation from Chinese into English, language acquisition

\section{Introduction}

With the rapid development of mass media, public discourse has increasingly intervened in social processes, impacted on people's thinking and behavior, and played a central role in the production and dissemination of ideology (Thompson 1990). The newspaper, as a typical form of mass media in modern and postmodern society, is playing a more significant role (Van Dijk 2001). If reading newspaper editorials is seen as a communicative event, the two sides of communication are the general public and the author 
who represents the newspaper's position. Newspaper editorials often claim to be "objective", "independent" and "fair". However, according to Critical Discourse Analysis (CDA) scholars, newspaper editorials and news reports are driven by various interests, values and ideological orientations; so in order to maintain their own ideology, authors of news reports and editorials intentionally use rhetorical strategies when presenting facts, and some of those strategies include referencing, highlighting, or emphasizing certain carefully selected facts, and blaming or trying to avoid blame. These strategies serve to influence the reader's emotions and views so that the author's ideology becomes more acceptable. Thus, they serve as a control mechanism to maintain social inequality and the economic interests of elites in a society (Fairclough 2013). In a word, they help shape power relations and the dissemination of ideology (Fairclough 1993: 8-10).

Fowler (1979) points out that since language provides a variety of means to express one's ideology, linguistic analysis and social analysis should become integrated, and discourse analysis needs to examine not only the 'explicit' tools of representing ideology in the text, such as the choice of particular vocabulary, but also the 'implicit' ideology-embedded notions, such as transitivity, classification, transformation, modality, and coherence. The former are easy to identify because they are primarily manifested in the meaning of a concept or in the proposition of a sentence, while the latter are not readily discernible because the hidden ideological meaning is often embedded in the premise, connotation, emotion, association and collocation. As a result, most of them have been naturalized and become seemingly common sense in order to exert subtle influence on language users.

Using a parallel translation corpus, this study employs transitivity analysis to reveal how translators of different competence levels use 'accusation-avoidance translation strategies' when they translate Chinese editorials into English. Due to research limitations, our transitivity analysis focuses on ergative verbs, which are considered the most effective means to avoid direct accusations.

\section{Literature review}

Fairclough (2013) indicates that there is no one-to-one relationship between the form and meaning of language: one form may be used to express a variety of meanings and one meaning can be expressed by various forms; thus the same event expressed in different forms may carry different meanings. Similarly, Halliday \& Matthiessen (1994) see language as composed of sets of inherent functions. They argue that one of the main functions of language is to construct the flux of experience, which they define as an experiential function. They further define the meaning expressed by experiential function as 'experiential meaning'. As to how to express experiential meaning in a language, they give high priority to transitivity as they find that experiential meaning can be most effectively expressed through the grammatical system of transitivity. They indicate that the choice of transitivity may reveal the writer's world view, and under the seemingly objective selection of grammatical structures hide a great deal of subjective information. Halliday \& Matthiessen (1994) and Fairclough (2013) distinguish between two types of 
grammatical forms to express underlying views referred to as congruent and incongruent (metaphorical). For example:

(1a) 100 demonstrators are dead.

(1b) 100 demonstrators died.

(1c) The police shot 100 demonstrators.

When violence occurs during a demonstration, particularly between the authorities and the protesters, what most concerns readers is who attacked whom. In this example, did the police attack the demonstrators, or did the demonstrators attack the police? (1a) is selected to describe only the state of an event, the attribute (of being dead) of the demonstrators. But it reveals nothing else such as the reason for death, how the demonstrators were killed, suicide or homicide? Similar to (1a), the choice of (1b) to use an intransitive verb (die) omitted the actor of the action (who or what causes the actor to die), and readers would still learn not enough about how the demonstrators died. Only (1c) uses 'the police' as the subject (actor) of the sentence and places the goal (demonstrators) of actor right behind the verb (shot). Such a sentence structure unambiguously locates the actor (the police) who provoked the death of the demonstrators. In this case, (1c) is called 'congruent expression', and (1a) and (1b) are 'incongruent /metaphorical expression'. Compared with (1a) and (1b), the use of a transitive verb 'shot' in (1c) maximizes the reader's access to the scene of the event, and its presentation of the event most closely matches the real situation. From (1a) to (1c), the sympathy with the protesters increases, and the sequence of the event gradually becomes clearer. This is precisely the result of the play of transitivity.

As Fairclough (1993) points out, there are different ways to arrange the participants and the environment component of the position, or to omit a component to convey their communicative intent, to guide the reader toward a particular direction from the perspective of a specific event. Any choice made has an important cultural, political and ideological significance. There are many motivations and means for the writer to select "incongruent/metaphorical expression" and one of them is to hide the actor of an action in order to mask the actor's responsibility for implementing the action and to avoid blaming the actor for any action. As this study concerns only the use of verbs to achieve blame avoidance, intransitive verbs will naturally become the focus of this study. This is due to a large extent to the use of an intransitive verb allowing only one participant of the process to be expressed. Except for the subject of the sentence, an intransitive verb does not point to any other objects involved in the process. Thus, the use of intransitive verbs often produces a false impression that a process happens automatically (Fairclough 1992). For example,

(2a) The car stopped.

(2b) The car was stopped.

Similar to (1b), (2a) does not hint at any performer of the action of stopping the car, giving an impression that the process (the car stops) occurs naturally without the intervention of any external force. However, although (2b) does not indicate the agent who 
performed the action, its use of passive voice suggests that there exists an agent different from the subject who performed the action. 'The car' as the subject of (2b) is the goal of the action (stopping the car). Therefore, the use of intransitive verbs may to some extent achieve the effect of concealing the performer of the action of stopping the car.

According to traditional English grammar (Quirk et al. 1972), English distinguishes transitive and intransitive verbs on the basis of the verb's functioning within a sentence. Transitive verbs require an object to complete their meaning: "She gave money to the church". Intransitive verbs do not require objects: "The building collapsed". Some verbs can be both transitive and intransitive: "The earthquake collapsed the building".

However, Halliday \& Matthiessen (1994) indicate that the distinction between transitive and intransitive verbs is not necessarily sufficient to analyze transitivity since dislocation may occur between transitive and intransitive verbs: the use of the former does not necessarily represent transitive processes and the latter intransitive processes. As shown below, in (3a) a transitive verb is used but it is difficult to say that the subject is the performer of the action (weighs); while in (3b) an intransitive verb is used, but it too appears that the subject (the cup) does not initiate the action (broke).

(3a) The parcel weighs ten pounds.

(3b) The cup broke.

Thus, Halliday \& Matthiessen (1994) distinguish between 'ergative verbs' and 'unergative verbs' in order to facilitate the possible understanding of transitivity. Ergative verbs refer to the verb used in a sentence where the subject does not actively initiate the action of the verb. They further classify ergative verbs into two groups: paired and unpaired. Verbs that can be used as both intransitive and transitive are referred to as paired ergative verbs (e.g. break, awake, open, grow, melt). We can build them into transitive verbs, such as "X wakes $\mathrm{Y}$ up", "X opens the door for $\mathrm{Y}$ " or "X grows $\mathrm{Y}$ "; they can also be used as intransitive verbs as in the sentences of "Y wakes up", "The door opens", or "Y grows". The other group of ergative verbs can only be used as intransitive verbs (e.g. die, fall), and they are called unpaired ergative verbs. The sentence using a paired ergative verb may easily be converted into an SVO structure. For example, "The baby woke" can be turned into "The baby was awakened by the mother". Although sentences using unpaired ergative verbs cannot directly be translated into an SVO structure, an SVO structure still can be realized by adding the causative verb 'cause'. For example, "An accident happened." can be converted into "Something caused an accident to happen". According to Halliday \& Matthiessen's (1994) definition, sentences using an ergative verb as the predicate show features of both the active voice and passive voice, which they refer to as the 'middle voice'. The 'middle voice' is active in form, but has a meaning equivalent to a passive, and it does not take the 'doer' of the verb into account.

The effectiveness of using ergative verbs to background the role of the agent has been recognized by many scholars. For instance, Halliday \& Matthiessen (1994) claim that the markedness of middle voice is stronger than that of passive voice, followed by active voice, and thus the use of ergative verbs could achieve the strongest effect of hiding the agent of an action and avoiding blame. Langacker (1987) discusses ergative verbs from 
a perspective of cognitive science and suggests that ergative verbs can de-focus the role of the executor of an action. Comrie (1989) argues that the choice of intransitive verbs or ergative verbs results in an emphasis on the action or process itself and detaches the executor from the action or process at hand.

A great deal of research has been done on how to de-focus the agent of an action or process (Langacker 1987; Fang 1994; Gerbig 1997; Comrie 1989; Hagiwara 1992; Stubbs 1994; Sotillo \& Starace-Nastasi 1999; Cai 2000; Fang 2001; Berk-Seligson 2002; Kuo \& Nakamura 2005; Yu 2006; Mo 2006; Li 2007; Lillian 2007; Murata 2007). For example, Fang (1994) compared the editing and reporting strategies used by a Chinese government-funded English newspaper when covering news events in its 'friendly' countries against those in the 'hostile' ones. It identified the choice of intransitive verbs as one of the manipulation tools used by this newspaper to portray the friendly countries as positive and hostile countries as negative based upon its own ideology. Fang (2001) critically examined what discourse strategies were used by two Chinese newspapers with opposite ideologies in their similar reports on two news events. The use of intransitive verbs was again identified as one of the manipulation tools used by these newspapers to achieve the desired interpretation of a reality they deemed suitable to different readerships. Kuo \& Nakamura (2005) looked at the differences between two newspapers with opposite ideologies when reporting the same news event, and they suggested that the choice of intransitive verbs, along with other grammatical and stylistic features was deliberately made by the two newspapers to manifest their underlying opposed ideologies. These studies have had significant implications for translation studies as the use of discourse strategies, including the use of intransitive verbs to achieve ideological aims in the trans-editing process of a news event, can also be adopted to achieve other purposes, such as avoiding blame. However, it appears that most of the studies were based on case studies and they did not go further than identifying intransitive verbs as just one of the 'de-focusing' strategies available to translators. There is a lack of empirical research on the role played by intransitive verbs, in particular ergative verbs, in news translation and editing processes.

In a more focused study of ergative verbs, Berk-Seligson (2002) looked at the use of ergative verbs by Spanish court interpreters and found that the interpreters chose ergative verbs to 'de-emphasize' the participation of the defendant in the alleged crime if they felt sympathetic towards the defendant. She argued that the use of ergative verbs effectively places the 'doer' of the action in the background and thus remains a way of avoiding direct blame. However, her study only focused on interpreting, which is different from translation where translators usually have much more time to choose appropriate words and sentences. The question how translators choose to render blaming avoidance strategies used in the source text still remains unanswered. In addition, research on the 'de-focusing' feature of ergative verbs is rare and inconclusive at best. For example, Gerbig (1997) compared the use of ergative verbs by industries, environmentalists, academics, and the media in their texts to represent the 'doer', 'causer' and 'responsibility' of environmental deterioration. His corpus-based study found no significant differences in the use of ergative verbs between the four corpora that contained texts from each of the four sources. As Gerbig indicates, such an outcome could result from the fact that 
the four groups, although having different opinions on some environmental issues, did not have fundamental conflict in their ideology, and a closer examination of ergative verbs and the context in which they are used is necessary. Therefore, this current study focuses on the use of ergative verbs, potentially one of the most effective means for translators to deal with blame avoidance strategies in the source text.

Ergative verbs have been extensively studied in the field of second language acquisition over the last thirty years from the early studies of Belleti \& Rizzi (1981), Perlmutter \& Postal (1984), Burzio (1986), Zobl (1989), Levin \& Rappaport (1992), and Yip (1995) to some recent ones (Ju 2000; Oshita 2000). Studies of intransitive and ergative verbs of different languages have found that EFL learners often make more mistakes in their use of ergative verbs than in the use of unergative verbs. Three main categories of ergative verbs misuse have been identified as follows:

1. Passivization of ergative verbs, e.g. using ergative verbs in the passive structure 'be+Ved'. For example, 'The leaves were fallen down.' (Yip 1995);

2. The use of ergative verbs in the V-NP structure. For example, 'I was just patient until dried my clothes.' (Zobl 1989);

3. The use of the copula ' $b e$ ' in front of ergative verbs. For example, 'The telegraph is remain.' (Richards 1971)

Studies of Chinese learners' acquisition of English ergative verbs generally support the above findings. In their study of the writing of Chinese learners, all of the above three types of errors have been found although error counts tend to be reduced when the translators' competence levels increase (Cai 2000; Mo 2006; Li 2007; Yu 2006). However, the majority of the studies have not included subjects with advanced levels of proficiency in English. In addition, these studies have mainly used writing compositions and multiple choice as research material, which according to Oshita (2000) may have influenced their outcome. As a result, research subjects could have avoided using certain verbs in composition writing research, and they might have guessed the answer in multiple-choice research.

In summary, traditional studies of verb transitivity mainly focused on whether the action carried out by an actor affected another object, and they only distinguish between transitive and intransitive verbs categories. There is a lack of studies related to ergative verbs that provide a cover for the actor of an action in order to avoid accusation and blame. Among the few studies of ergative verbs, fewer still have directly addressed the pragmatic function of ergative verbs to avoid accusations. In addition, studies of ergative verbs have been carried out mainly in the field of English writing, and the results are yet to be extended to translation studies. Therefore, this study aims to explore the characteristics of using ergative verbs in the translation of accusation-avoidance expressions by native Chinese-speaking translators. The specific research questions are as follows.

1. What are the frequencies of ergative verbs in the translation when translators of different translation competence levels translate accusation-avoidance expressions?

2. What is the relationship between the use of the "ergative verb" and the translator's competence level when they translate accusation-avoidance expressions? Is there a significant difference between translators of difference competence levels? 


\section{Research methods}

\subsection{Subjects}

This study recruited 10 translators from each of the following categories:

1. 4th year university undergraduates majoring in translation and interpretation studies;

2. Post-graduates majoring in translation and interpretation studies; and

3. Professional translators.

All subjects were native Chinese speakers. The professional translators had worked as professional translators for major translation agencies located in Taiwan, mainland China, and Australia, and all of them had at least five years of practical translation experience when the data were collected.

\subsection{Corpus data collection}

The researchers selected five editorial articles in Chinese from authentic Chinese newspapers, truncated them to about 300 to 350 words sections, and asked the subjects to translate them into appropriate English that reads as fluently and naturally as possible. A total of 150 translations were collected.

\subsection{Corpus data extraction}

We processed all source sentences and target sentences, and created a bilingual parallel corpus using the WinAlign function provided by the Trados 7.0, a translation software package, to pair the target sentences with the source sentences. We carefully read the 5 Chinese texts to identify the sentences directly meant to "avoid accusations", and then used the Concordance function of the software to search and export each pair of target sentence together with the source sentence meant to avoid accusations. All the data were then imported into SPSS datasheet for purposes of statistical analysis. A total of 1367 effective translation units were extracted in this study. For example, the following is an accusation-avoidance sentence in Source text 2, and its translation was extracted from the corpus:

\section{Source:「但日本的經濟從而停滯了十幾年」}

Target: but Japan's economy stagnated for more than a decade.

A Trados Concordance search found a total of 99 pairs as shown in Figure 1. Given that ergative verbs lack the autonomy, a verb is deemed to be ergative if it does not make sense by adding an adverb such as 'intentionally' or 'willingly'.

Furthermore, we used a list of 430 ergative verbs contained in the Collins Cobuild Dictionary as a criterion to determine whether or not the verbs used by the translator's translation were ergative. We only analyzed 200 randomly sampled data due to the time constraints. 


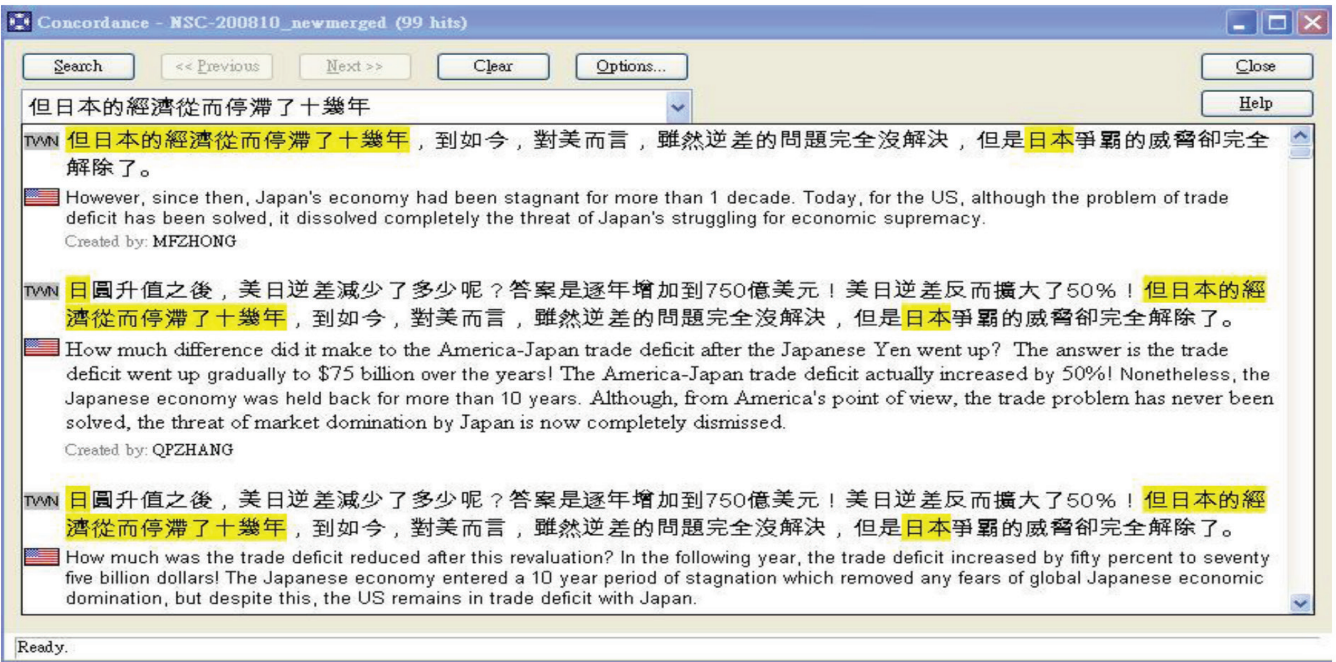

Figure 1. An example of Trados concordance search results

\subsection{Data annotation}

We used the following codes to mark the 200 sentences:

1. Translation number;

2. Translator category; $1=4$ th year undergraduate; 2 = graduate; 3 = professional; and,

3. The accusation-avoidance translation strategies were classified as follows: $1=$ ergative verb; 2 = others.

\subsection{Data analysis}

To answer Research Question 1, cross-tabulation analysis was used to present the number of times ergative verbs were used by the translators in each group. We then used one-way ANOVA to test the relationship between the translator's category and their use of ergative verbs to answer Research Question 2.

\section{Results}

\subsection{The frequencies of ergative verbs in the translation}

In order to understand the differences in the use of accusation-avoidance strategies by the three groups of translators, we cross-tabulated the two variables of "translator category" and "accusation avoidance translation strategies". Table 1 shows the 200 randomly selected cases consisting of 65 from the Undergraduate group, 68 from the Graduate, group and 67 from the Professional Group. Among these 200, the use of ergative verbs 
Table 1: Translator level and the use of ergative verbs

\begin{tabular}{|c|c|c|c|c|}
\hline \multicolumn{5}{|c|}{ Translator levels $*$ Use of ergative verbs } \\
\hline & & \multicolumn{2}{|c|}{$\begin{array}{l}\text { Accusation-avoidance } \\
\text { translation strategies }\end{array}$} & \multirow[b]{2}{*}{ Total } \\
\hline & & Ergative verbs & Other & \\
\hline \multirow[t]{3}{*}{ Undergraduate } & Count & 51 & 14 & 65 \\
\hline & $\%$ within translator levels & $78 \%$ & $22 \%$ & $100 \%$ \\
\hline & $\%$ within use of ergatives & $39.5 \%$ & $9.7 \%$ & $62 \%$ \\
\hline \multirow[t]{3}{*}{ Graduate } & count & 41 & 27 & 68 \\
\hline & $\%$ within translator levels & $60 \%$ & $40 \%$ & $100.0 \%$ \\
\hline & $\%$ within use of ergatives & $31.8 \%$ & $22.7 \%$ & $24.0 \%$ \\
\hline \multirow[t]{4}{*}{ Professional } & count & 37 & 30 & 67 \\
\hline & $\%$ within translator levels & $55.2 \%$ & $44.8 \%$ & $100.0 \%$ \\
\hline & $\%$ within use of ergatives & $29 \%$ & $29.9 \%$ & $29.5 \%$ \\
\hline & Count & 129 & 71 & 200 \\
\hline
\end{tabular}

is the primary strategy chosen with a total count of 129 against other accusation-avoidance translation strategies with a total count of 71 . And, it is also the most frequently used strategy by translators of the three different levels (78\% by Undergraduate, $60 \%$ by Graduate, and $55.2 \%$ by Professional). The percentages indicated by boldface numbers in Table 1 show the frequency count of using ergative verbs by translators in each of the three levels. The undergraduate translators account for the highest frequency (39.5\%), followed by the Graduate translators (31.8\%), and the professional translators (29\%). Evidently, the use of ergative verbs decreases when the translator's translation competence level increases.

\subsection{The use of ergative verbs and the translator's competence level}

Although the answer to Research Question 1 shows that the use of "ergative verbs" differs between translators with different translation competence levels, it does not show whether the differences are statistically significant. Therefore, we carried out a one-way ANOVA test, using the "Accusation-avoidance translation strategies" as the dependent variable and "Translator Levels" as the influencing factor. The boldfaced numbers in Table 2 show that undergraduate translators differ from the other two groups significantly in their use of accusation-avoidance translation strategies $(p=0.000<0.05)$, and the difference between graduate and professional translators does not reach a significant level $(p=0.071>0.05)$. 
Table 2: One-way ANOVA test

Multiple comparisons

Dependent variable: Accusation-avoidance translation strategies

\begin{tabular}{|c|c|c|c|c|c|c|}
\hline \multicolumn{7}{|c|}{ LSD } \\
\hline \multirow{2}{*}{ (I) Translator levels } & \multirow{2}{*}{ (J) Translator levels } & \multirow{2}{*}{$\begin{array}{c}\text { Mean } \\
\text { Difference } \\
(\mathrm{I}-\mathrm{J})\end{array}$} & \multirow{2}{*}{ Std. Error } & \multirow{2}{*}{ Sig. } & \multicolumn{2}{|c|}{$\begin{array}{c}95 \% \text { confidence } \\
\text { interval }\end{array}$} \\
\hline & & & & & $\begin{array}{l}\text { upper } \\
\text { bound }\end{array}$ & $\begin{array}{l}\text { lower } \\
\text { bound }\end{array}$ \\
\hline \multirow{2}{*}{ Undergraduate } & Graduate & -0.320 & 0.330 & 0.000 & -0.67 & 0.43 \\
\hline & Professional & -0.567 & 0.251 & 0.000 & -1.30 & -0.62 \\
\hline \multirow{2}{*}{ Graduate } & Undergraduate & 0.320 & 0.330 & 0.000 & -0.43 & 0.67 \\
\hline & Professional & -0.417 & 0.390 & 0.071 & -1.31 & -0.61 \\
\hline \multirow{2}{*}{ Professional } & Undergraduate & 0.320 & 0.330 & 0.000 & 0.62 & 1.30 \\
\hline & Graduate & 0.417 & 0.390 & 0.071 & 0.61 & 1.31 \\
\hline
\end{tabular}

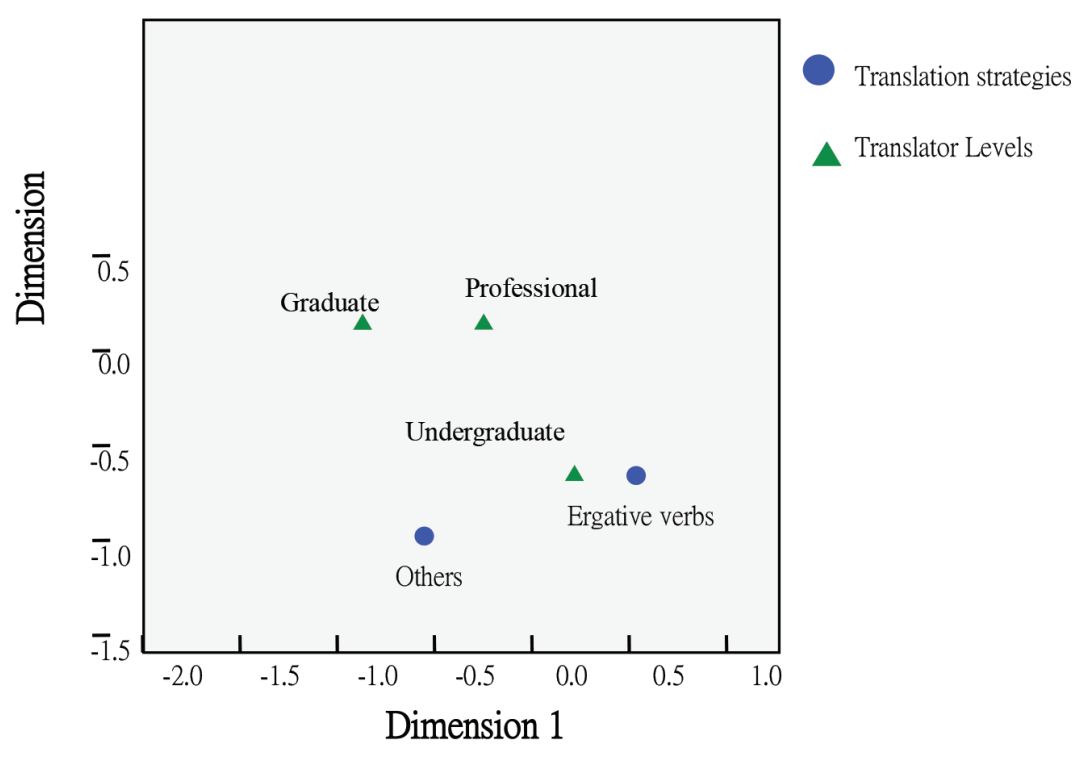

Figure 2. Correspondence of "Translator levels" and "Accusation-avoidance translation strategy"

We further used the two variables, "Translator levels" and "Accusation-avoidance translation strategies", to perform a correlation analysis and plotted the correlation rela- 
tionships between translator levels and the use of accusation-avoidance translation strategies in a two-dimensional diagram (Figure 2). Figure 2 shows that the "Ergative verbs" category of the Accusations-avoidance variable is very close to the "Undergraduate" category of the Translator Levels variable, while the other categories of the two variables are further apart. This result shows that the use of ergative verbs to translate accusation-avoidance expressions is a distinct feature of the undergraduate translators.

\section{Discussion}

\subsection{The use of ergative verbs and the acquisition of English}

The results for Research Question 1 show that when translating accusations-avoidance expressions, less proficient translators tend to use more ergative verbs, and the frequency of using ergative verbs tends to decrease with the improvement of their translation competence levels and general language proficiency. However, the results of previous studies on language acquisition have pointed out that less advanced/beginner English learners tend to use fewer ergative verbs (Cai 2000; Mo 2006; Yu 2006; Li 2007). This discrepancy most likely results from using different samples in the studies. This study used translations, while the above studies used English compositions. While writers can avoid using unfamiliar words, translators who are especially less experienced are constrained by the original text and sometimes they must use words that they are less familiar with (Campbell 1998). We thus propose that undergraduate translators would make more mistakes in their use of ergative verbs despite their frequent use of them, and an examination of the corpus data supports this view. The following examples extracted from the corpus are produced by undergraduate translators when using ergative verbs, in which all 3 types of errors found by previous studies (Richards 1971; Zobl 1989; Yip 1995) have appeared.

(1) ST: 今年進出口年增率落入個位數, 應是相對於鄰近國家持續滑落趨勢的一種 延伸, 而非開始。

TT1: The annual growth rate of imports and exports was fallen to a singular digit and it can be seen as an extension of the neighboring countries' continually declining trends instead of a phenomena. (passivization of an ergative verb )

TT2: This year, the import and export growth rate is reduced to a single digit number, which instead of a phenomena, might be an extension to the falling rate alike the neighboring countries. (passivization of an ergative verb)

(2) ST: 近期進出口年增率表現不甚理想

TT1: Recently, the increase rate of import and export has performed dissatisfaction. (the use of ergative verbs in the V-NP structure)

TT2: Our recent import and export increase rate is not well performed. (adding the copula $b e$ in front of an ergative verb) 
The source texts (ST) in Examples (1) and (2) are both extracted from an article that supports government economic measures and defends the decline in import and export growth rates under the government's current economic policy (see Appendix A). Therefore, both ST sentences use intransitive verbs (boldfaced Chinese characters) to refer to the decrease in import and export growth rates to avoid possible accusation of the government. Although the undergraduate translators have chosen ergative verbs (boldfaced English words) in their translation, they all made mistakes, as pointed out. This may indicate that the translators have not acquired a proper level of usage of these ergative verbs. Based on our experience of teaching translation, the undergraduate translators' choice of ergative verbs is not likely to be based on a true understanding of the pragmatic purpose of avoiding accusation. Therefore, the ergative verbs may result from word-for-word translation of the verbs in the source article.

In this regard, our findings are not inconsistent with previous studies. The undergraduate translator's extensive use of ergative verbs in their translation may not necessarily indicate that they have consciously used ergative verbs to achieve the purpose of avoiding accusation. In addition, they have made a large number of mistakes when using such verbs, which should be targeted in subsequent studies in order to provide evidence related to the acquisition of English ergative verbs by native Chinese-speaking learners.

In addition, our study has found that there is no significant difference in the frequency of using ergative verbs between graduate and professional translators (Table 2). This finding supports the view that the acquisition of ergative verbs is difficult to accomplish for learners with lower English competence levels and those at advanced levels alike (Zobl 1989; Yip 1995; Cai 2000; Oshita 2000). This is evident when we see that the graduate and professional translators in this study made similar mistakes as the undergraduate translators when using ergative verb forms. Although using ergative verbs for the V-NP structure and adding the copula be in front of an ergative verb are rare for these two groups of translators, they passivize ergative verbs as frequently as undergraduate translators may.

\section{(3) ST: 美國政府一再呼籥筫：人民幣應對美元升值}

TT1: The American government repeatedly asks for the RMB to be revaluated over the Dollar. (Professional translator)

TT2: The US government repeatedly appealed that RMB should be appreciated against the US dollar in order to alleviate the enormous Sino-US trade deficit. (Professional translator)

TT3: The American government has been calling for the value of Chinese Yuan (Renminbi) to be increased against the US dollar to reduce the trade deficit between the two countries. (Graduate translator)

TT4: The U.S. kept requesting that the RMB should be appreciated against USD to shorten the huge business deficit. (Graduate translator)

Clearly, the translators of TT1-4 have not acquired the proper usage of the ergative verbs of revaluate and appreciate, resulting in the mistakes of passivizing the two ergative verbs. 


\subsection{Ergative verbs and accusation-avoidance translation strategies}

Previous studies have found that using intransitive verbs (including ergative verbs discussed in this study) can achieve the pragmatic purpose of avoiding accusations, and that native English speakers tend to be more confident in using ergative verbs when writing compositions (Sotillo \& Starace-Nastasi 1999; Fang 2001; Berk-Seligson 2002; Kuo \& Nakamura 2005; Lillian 2007; Murata 2007). However, these studies were largely based on analyzing texts from composition writing sources. The analysis of translations by native Chinese-speaking translators in this study provides fresh evidence that supports the findings. This study has found that translators of high language proficiency and a higher translation competence level (i.e. graduate and professional translators) often use other expressions when they could use ergative verbs. The following are some examples.

(4) ST: 日本的經濟從而停滯了十幾年。

TT1: As a result, Japan's economy remained stagnant for more than a decade. (Professional translator)

TT2: The Japanese economy, as a result, entered stagnation of over ten years. (Professional translator)

TT3: It resulted in the Japanese economy stagnant for more than a decade. (Graduate translator)

TT4: Japan had even experienced a prolonged sluggish growth for ten years since then. (Graduate translator)

The ST sentence in the article (see Appendix B) uses an intransitive verb $\ulcorner$ 停滞 $\lrcorner$ to avoid accusing the actor (the Japanese government) who should be responsible for Japanese economic stagnation. Translators may well use the ergative verb "stagnate", readily available in English, to translate the sentence into "However, Japan's economy stagnated for over a decade" (the author's translation). However, none of the 4 translators has chosen to use any ergative verbs in this case. In particular, the translator of TT3 has made an unwarranted accusation of the government by using "It resulted in...", which has violated the ST's purpose of not blaming the government for economic stagnation.

The above examples show that the graduate and the professional translators may not have properly taken into account the ST's intention of avoiding accusations when making verb choice. Of course, it is also possible that the translators have purposefully chosen the above verbs to represent their own ideological stance. Although we cannot be certain of the real reason behind the translators' choices without interviewing them, we would suggest that the explanation lies in their lack of awareness of the pragmatic purpose of avoiding accusation in the ST based on the results of previous research on language acquisition. 


\section{Conclusions}

The results of this paper show that: 1) Native Chinese-speaking learners of English at high levels of proficiency, such as graduate and professional translators, are able to use a significant number of English ergative verbs in their translation of accusation-avoidance expressions. However, the accuracy of their usage of ergative verbs needs improvement since a large number of such ergative verbs have been used incorrectly; 2) The development of learners' acquisition of ergative verbs is not visible as indicated by the marginal difference between the graduate and professional translators in their use of ergative verbs to translate accusation-avoidance expressions. There is no statistically significant difference between the two groups; and, 3) Although using ergative verbs is an effective means to avoid accusation in English, native Chinese-speaking translators may not have paid enough attention to it. Therefore, it is suggested that teaching English and translation should focus on the learner's understanding and usage of ergative verbs to help learners master the grammatical and semantic features peculiar to English ergative verb features.

This study has the following limitations. First, our translation corpus is relatively small in size. Although entries in our parallel translation corpus were highly homogeneous, there were only 30 translators in total taking part in this study, which may affect the accuracy of the results. Second, this study did not use a questionnaire survey of translators, and thus could not reveal the precise reasons why translators chose certain ergative verbs versus other available choices and how they see mistakes they make. Future studies may look at the use of paired/unpaired ergative verbs in translation. In addition, researchers may also classify ergative verbs based on semantic differences to investigate the influence of such internal semantic differences on the errors.

\section{Appendices}

Appendix A

出口成長率落後誰是禍首

日前財政部公布今年進出口年增率不甚理想, 泛藍學媒就紛紛數落政府兩岸政策 之不是, 影響對中國出口增加率下降。此種昧於事實伎倆本不值一駁, 惟為了社會 能免於誤謬, 我們還是要再次慎重提醒國人, 正確認識此事的真正原因。

的確, 近期進出口年增率表現不甚理想, 但我們必須了解, 自從政府採行「積極 開放」政策後, 經濟成長率就開始落後於鄰近國家。今年進出口年增率落入個位 數，應是相對於鄰近國家持續滑落趨勢的一種延伸，而非開始。

要了解進出口成長率持續落後的因果關聯其實不難。當廠商將生產基地轉移至中 國之後, 其產品之出口當然就成為中國之出口, 所以對中國之生產性投資越多, 出 口被取代之比率則越高。

顯而易見, 當今台灣之經濟問題是採取「積極開放」政策的結果。但不幸的是, 這些經濟問題常被泛藍親中學媒扭曲, 成為對中國不夠開放的代罪羔羊, 此次出口 成長率之下降亦復如是, 希望執政的經濟官員不要再為泛藍的謬論所誤。 


\section{Appendix B}

\section{美國要人民幣升值的真正目的}

美國政府一再呼䈁筫：人民幣應對美元升值，以改善中美巨額貿易逆差。美國催促 人民幣升值的真正目的, 絕對不是要解決其貿易赤字, 因為人民幣再怎麼升值, 也 解決不了這個問題。

1980年代，日本是美國的最大逆差來源國，約四百多億美元。那時在汽車、半導 體、家電等領域，「日本第一」的威脅聲響遍雲霄。於是，在1985年，美國聯合歐 洲強迫日本接受「廣場協定」，讓日圓跟美元脫鉤，開始對其升值。結果日圓從約 250 日圓兌一美元, 逐漸升值到約 100 日圓兌一美元。日圓升值之後, 美日逆差減少 了多少呢? 答案是逐年增加到750億美元！美日逆差反而廣大了 $50 \%$ ! 但日本的經濟 從而停滯了十幾年, 到如今, 對美而言, 雖然逆差的問題完全沒解決, 但是日本爭 霸的威脅卻完全解除了。

當時美國逼迫日圓升值所用的說詞和手法跟現在強逼人民幣升值的方式有著驚人 的相似。不同的是, 日本在軍事、外交上仰賴美國, 沒有說「不」的權利。殷鑑不 遠，難怪中國現在不買美國的帳。

\section{References}

Belletti, Adriana \& Rizzi, Luigi. 1981. The syntax of "ne": some theoretical implications. The Linguistic Review 1(2). 117-154.

Berk-Seligson, Susan. 2002. The bilingual courtroom: Court interpreters in the judicial process. Chicago: University of Chicago Press.

Burzio, Luigi. 1986. Italian Syntax: A Government-Binding Approach. Dordrecht: Reidel.

Comrie, Bernard. 1989. Language universals and linguistic typology. Chicago: University of Chicago Press.

Fairclough, Norman. 1993. Discourse and social change. Cambridge, UK: Polity.

Fairclough, Norman. 2013. Language and power. London: Routledge.

Fang, Yew-Jin. 1994. Riots' and demonstrations in the Chinese press: a case study of language and ideology. Discourse \& Society 5(4). 463-481.

Fang, Yew-Jin. 2001. Reporting the same events? A critical analysis of Chinese print news media texts. Discourse \& Society 12(5). 585-613.

Fowler, Roger. 1979. Language and control. London: Routledge \& K. Paul.

Gerbig, Andrea. 1997. Lexical and grammatical variation in a corpus: a computer-assisted study of discourse on the environment. Frankfurt: Peter Lang.

Hagiwara, Shigeru. 1992. The concept of responsibility and determinants of responsibility judgment in the Japanese context. International Journal of Psychology 27(2). 143-156.

Halliday, Michael A. \& Matthiessen, Christian M. 1994. An introduction to functional grammar. New York: Routledge.

Ju, Min Kyong. 2000. Overpassivization errors by second language learners. Studies in Second Language Acquisition 22(1). 85-111.

Kuo, Sai-Hua \& Nakamura, Mari. 2005. Translation or transformation? A case study of language and ideology in the Taiwanese press. Discourse \& Society 16(3). 393-417.

Langacker, Ronald W. 1987. Transitivity, case, and grammatical relations: a cognitive grammar prospects. Duisburg: Duisburg University.

Levin, Beth \& Hovav, Malka Rappaport. 1992. The lexical semantics of verbs of motion: the perspective from unaccusativity. In Roca, I. M. (ed.), Thematic structure: its role in grammar, 247-269. Berlin: Foris.

Lillian, Donna L. 2007. A thorn by any other name: sexist discourse as hate speech. Discourse \& Society 18(6). 719-740. 
Murata, Kumiko. 2007. Pro-and anti-whaling discourses in British and Japanese newspaper reports in comparison: A cross-cultural perspective. Discourse \& Society 18(6). 741-764.

Oshita, Hiroyuki. 2000. What is happened may not be what appears to be happening: a corpus study of "passive" unaccusatives in L2 English. Second Language Research 16(4). 293-324.

Perlmutter, David \& Postal, Paul. 1984. Impersonal passives and some relational laws. In Perlmutter, David \& Rosen, Carol (eds.), Studies in relational grammar, Vol. 2. 126-170. Chicago: The University of Chicago Press.

Quirk, Randolph \& Greenbaum, Sidney \& Leech, Geoffrey \& Svartvik, Jan. 1972. Grammar of Contemporary English. London: Longman.

Richards, Jack. 1971. A Non-Contrastive Approach to Error Analysis. English Language Teaching 25(3). 204-219.

Sotillo, Susana M. \& Starace-Nastasi, Dana. 1999. Political discourse of a working-class town. Discourse \& Society 10(2). 249-276.

Stubbs, Michael. 1994. Grammar, text, and ideology: computer-assisted methods in the linguistics of representation. Applied Linguistics 15(2). 201-223.

Thompson, John B. 1990. Ideology and Modern Culture: Critical Social Theory in the Era of Mass Communication. Cambridge, UK: Polity.

Van Dijk, Teun A. 2001. Critical discourse analysis. In Schiffrin, Deborah \& Tannen, Deborah \& Hamilton, Heidi E. (eds.), The handbook of discourse analysis, 352-371. Oxford: Oxford University Press.

Yip, Virginia. 1995. Interlanguage and learnability: from Chinese to English, Vol. 11. Amsterdam: John Benjamins.

Zobl, Helmut. 1989. Canonical typological structures and ergativity in English L2 acquisition. In Gass, Susan \& Schachter, Jacquelyn (eds.), Linguistic Perspectives on Second Language Acquisition, 203-221. Cambridge, UK: Cambridge University Press.

Yu, Jianyao (俞建燿). 2006. Yīngyǔ fēi bīn gé dòngcí zài wàiyǔ xídé guòchéng zhōng de bèidòng fàn huà zònghé jiěshì (英語非賓格動詞在外語習得過程中的被動泛化綜合解釋) [The pattern of overpassivization of unaccusative verbs by learners of English in China]. Journal of Xi'an International Studies University 14. 40-43.

Li, Rui (李睿). 2007. Zhōngguó yīngyǔ xuéxí zhě zuò gé dòngcí bèidòng huà cuòwù-yī xiàng jīyú CLEC de yánjiū (中國英語學習者作格動詞被動化錯誤 - 一項基於 CLEC 的研究) [A CLEC study of passivization of ergative verbs in errors made by Chinese learners of English]. Social Sciences Review 22. 167-172.

Mo, Junhua (莫俊華). 2006. Jĩyú yǔliàokù de fêi bīn gé dòngcí bèidòng huà de yuányīn fēnxī-jiān yǔ Hiroyuki Oshita bóshì shāngquè (基於語料庫的非賓格動詞被動化的原因分析 - 兼與 Hiroyuki Oshita 博士商榷) [A corpus-based analysis of passivization of unaccusative verbs in response to Dr. Oshita]. Foreign Language Education 6. 13-18.

Cai, Jinting (蔡金亭). 2000. Zhōngguó xuéshēng yīngyǔ guòdù yǔ zhòng de zuò gé dòngcí-yī xiàng shízhèng yánjiū (中國學生英語過渡語中的作格動詞 - 一項實證研究) [Ergative verbs in Chinese students' interlanguage - An empirical study]. Foreign Language Teaching and Research 32. 283-289. 